\title{
ANALISIS PERPUTARAN PIUTANG SEBELUM DAN SESUDAH PERUBAHAN TARIF PADA PDAM KOTA SALATIGA
}

\author{
Sofi Agustina ${ }^{1)}$, Agustina Prativi Nugraheni ${ }^{2)}$ \\ 12) Program Sudi S1 Akuntansi, Fakultas Ekonomi Universitas Tidar \\ Jl. Kapten Suparman No.39, Tuguran, Potrobangsan, Kec. Magelang Utara, Kota Magelang, \\ Jawa Tengah 56116, Indonesia \\ 1) sofiagustina08@gmail.com \\ 2) devi.agustina@untidar.ac.id
}

Diterima: 30 Agustus 2020. Disetujui: 28 Desember 2020. Dipublikasikan: Desember 2020

\begin{abstract}
Abstrak
Penelitian ini berguna untuk Analisis Perputaran Piutang Usaha setelah dan sebelum, Setelah Perubahan Tarif di Kota Salatiga. Perusahaan Air Minum Daerah (PDAM) adalah Badan Usaha Milik Daerah (BUMD) yang dibentuk oleh Pemerintah untuk menyediakan layanan, yaitu distribusi air bersih dari sumur atau mata air ke seluruh wilayah Kota Salatiga. Penyesuaian tarif air merupakan komponen penting dalam mengukur piutang. Metode penelitian yang digunakan dalam penelitian ini adalah metode kualitatif. Berdasarkan analisis yang dilakukan, pencatatan piutang air didasarkan pada jumlah total air yang didebitkan oleh pelanggan dan tarif kelompok pelanggan. Dengan demikian mengakibatkan peningkatan penyesuaian tarif air dapat memperlambat sirkulasi piutang yang terjadi di PDAM Kota Salatiga. Perputaran piutang sebelum mengalami kenaikan tarif 9,51 kali, sedangkan setelah mengalami kenaikan tarif turun menjadi 6,70 kali setiap tahun. Sehingga, perputaran piutang sebelum kenaikan tarif lebih efektif dibandingkan dengan perputaran piutang setelah terjadi kenaikan tarif.
\end{abstract}

Kata kunci: perputaran piutang, penyesuaian tarif, PDAM

\begin{abstract}
This study aims to determine the Analysis of Accounts Receivable Turnover Before and After Tariff Changes in the City of Salatiga. Regional Drinking Water Company (PDAM) is a RegionalOwned Enterprise (BUMD) formed by the Government to provide services, namely the distribution of clean water from wells or springs to all areas of Salatiga City. Adjustment of water tariffs is an important component in measuring receivables. The research method used in this study is a qualitative. Based on the analysis conducted, the recording of water receivables is based on the total amount of water debited by the customer and the customer's group rate. Thus resulting in increased water tariff adjustments can slow down the circulation of receivables that occur in PDAM Salatiga City. Receivables turnover before experiencing a rate increase of 9.51 times, whereas after experiencing a rate increase decreased to 6.70 times each year. Thus, the accounts receivable turnover before the rate increase is more effective than after the rate increase.
\end{abstract}

Keywords: accounts receivable turnover, tariff adjustments, PDAM

\section{PENDAHULUAN}

Kebutuhan akan air bersih merupakan suatu kebutuhan yang sangat bermanfaat bagi berbagai kalangan masyarakat. Kebutuhan air bersih yang berkualitasnya akan menjadi tuntutan masyarakat. Karena setiap kegiatan masyarakat dalam berbagai aspek kelangsungan hidup manusia, sudah memahami betapa pentingnya air bersih. Dengan pemanfaatan sumber daya alam bagi Kota Salatiga diharapkan mampu untuk memenuhi kebutuhan air bersih masyarakat. 
Pemerintah mendirikan PDAM untuk menyediakan air bersih yang struktur organisasinya bertumpu pada pemerintah daerah. Terlebih Kota Salatiga merupakan kota yang berada dibawah kaki gunung sehingga mempunyai sumber air yang baik.

Dalam bidang jasa, PDAM (Perusahaan Daerah Air Minum) ini memberikan jasa pengalokasian air bersih dari sumber mata air yang terbaik disetiap daerah itu sendiri. Pelayanan pengalokasian ini bertujuan untuk mencukupi kebutuhan air bersih di seluruh daerah baik pedesaan maupun Kota Salatiga. Pendapatan kas Perusahaan Daerah Air Minum (PDAM) Kota Salatiga memiliki 2 aliran dana yang pokok yaitu pendapatan Kas dar tagihan rekening pelanggan. Aliran dana tersebut dapat memenuhi operasional perusahaan. Untuk mencapai pelayanan bagi masyarakat agar memuaskan bagi perusahaan daerah dengan melakukan identifikasi faktor yang sudah ada dan yang signifisikanakan sangat berpengaruh kepada pencapaian sasaran. Menejemen PDAM di tuntu dapat memanfaatkan data keuangan yang ada pada laporan kauangan PDAM dengan maksimal, aga dapat diketahui tingkat kerja keuangan Perusahaan Daerah Air Minum. Keuangan yang di sampaikan oleh Perusahaan dalam bentuk neraca, Lporan rugi laba dan laporan arus Kas. Keputusab Mentri Dalam Negri (KEPMENDAGRI) No. 47 Tahun 1999 tentang Pedoman Penilaian Kinerja Perusahaan Daerah Air Minum menjadi landasan pengukuran tingat keberhasilan PDAM dan menjadi cerminan dari kinerja administrasi perusahaan Air Daerah Air Minum.

Perusahaan Daerah Air Minum harus meyajikann aset lancar dan aset tidak lancar kewajiban jangka pendek dan jangka panjang sebagai unsur suatu klarifikasi yang berbeda minimal mencakup pos antara lain, kas, piutang,piutang non usaha, kewajiban pajak, ekuitas (SAK-ETAP PDAM 2015 : 42). Pada penelitian kali ini, peneliti akan menganalisis tentang piutang pada neraca PDAM Klasifikasi dan penyajian dalam bentuk neraca setiap jenis piutang dibuka pada buku besar. Semua piutang diharapkan akan ditagih menjadi kas dalam jangka waktu setahun di neraca di sajikan sebagai aktiva lancer.

Komponen penting dalam pengukuran piutang rekening air pada PDAM adalah penyesuaian tarif. Dalam klasifikasinya, PDAM mempunyai penentuan tarif yang berbeda-beda sesuai dengan upah minimum di daerah tersebut. Penentuan tarif dengan penggolongan pelanggan yang sudah dibuat dinilai terjangkau dan tidak memberatkan keuangan oleh setiap masyarakat. Juheri (2008:1) mengungkapkan "Tarif air merupakan salah satu unsur penentu untuk memperoleh pendapatan PDAM, sedangkan pendapatan sangat penting untuk kegiatan operasional PDAM. Pendapatan PDAM yang utama berasal dari jumlah penjualan air dan sangat tergantung dari besar kecilnya tarif air yang berlaku."

Tahun 2018, PDAM Kota Salatiga telah membuat ketentuan penyesuaian tarif yang baru karena sejak tahun 2014 lalu belum pernah menaikkan tarif air. Mawiti (2020) mengatakan bahwa "PDAM harus menaikkan tarif dasar air karena merupakan salah satu persyaratan PDAM dalam hal restrukturisasi hutang. Perhitungan dan penetapan tarif dasar air didasarkan pada prinsipprinsip, yaitu: keterjangkauan dan keadilan, mutu pelayanan, pemulihan biaya secara penuh, efisiensi pemakaian air, transparansi, akuntabilitas dan perlindungan air baku."

Salah satu faktor kenaikan tarif dikarenakan tarif air bersih PDAM Salatiga terhitung masih rendah dibandingkan dengan tarif yang ditetapkan PDAM di Jawa Tengah lainnya. Selain itu, faktor lain yang menyebabkan kenaikan tarif adalah kenaikan tarif listrik, inflasi, harga BBM, kenaikan harga barang dan biaya operasional PDAM yang mendukung naiknya tarif PDAM Salatiga. Kenaikan tarif tersebut amanat dan perintah Permendagri Nomor 71 Tahun 2016 tentang perhitungan dan penetapan tarif PDAM. Di dalam aturan tersebut, seluruh PDAM di Indonesia menyesuaikan tarif sesuai yang ditetapkan Kemendagri agar terjadi full cost recovery sesuai analisis tim KEMENDAGRI.

Berdasarkan latar belakang yang telah dijelaskan, maka perlu dilakukan penelitian mengenai analisis perputaran piutang di Kota Salatiga sebelum dan sesudah dilakukannya kenaikan tarif air bersih oleh PDAM Kota Salatiga tahun 2018. 


\section{TINJAUAN PUSTAKA \\ Piutang}

Piutang merupakan unsur modal kerja yang berhubungan langsung dengan kegiatan operasi perusahaan. Perusahaan melakukan penjualan barang secara kredit akan menimbulkan piutang. Kebijakan penjualan secara kredit dilakukan perusahaan untuk meningkatkan penjualan dan laba, namun di pihak lain hal ini akan mengakibatkan peningkatan biaya yang timbul terkait dengan piutang (Sudana, 2011:217). Menurut Hery (2013:181) menyatakan bahwa yang dimaksud dengan piutang adalah sebagai berikut: "Piutang meliputi semua klaim dalam bentuk uang terhadap pihak lainnya, ternasuk individu, perusahaan atau organisasi lainnya."

Piutang menurut Standar Akuntansi Keuangan (SAK) pada PDAM "Piutang adalah hak tagih PDAM kepada pihak lain sebagai akibat penyerahan barang atau jasa di masa lalu. Piutang terdiri dari dua elemen yaitu piutang usaha dan piutang non usaha. Piutang usaha adalah piutang yang timbul dari transaksi penjualan air dan non air, sedangkan piutang non usaha adalah piutang yang timbul dari transaksi lainnya". Skousen (2004:479) mengungkapkan "piutang merupakan hak atau klaim terhadap pihak lain atas uang, barang atau jasa. Secara sempit untuk tujuan akuntansi, piutang didefinisikan sebagai klaim yang diharapkan akan selesai dengan diterimanya uang tunai (kas)."

\subsection{Perputaran Piutang (Receivable Turnover)}

Menurut Munawir (2002) memberikan keterangan bahwa "posisi piutang dan taksiran waktu pengumpulan data dapat dinilai dengan menghitung tingkat perputaran piutang tersebut, yaitu dengan membagi total penjualan kredit (netto) dengan piutang rata-rata." Sedangkan menurut Kasmir (2012:176) menyatakan bahwa "perputaran piutang merupakan rasio yang digunakan untuk mengukur berapa lama penagihan piutang selama satu periode atau berapa kali dana yang ditanam dalam piutang ini berputar dalam satu periode". Dengan demikian dapat diketahui semakin tinggi rasio perputaran piutang menunjukkan bahwa modal yang digunakan perusahan semakin efisien.

Soemarso (2010) menyatakan bahwa perputaran piutang adalah : "menunjukkan beberapa kali suatu perusahaan menagih piutangnya dalam suatu periode. Perputaran piutang menunjukkan efisiensi perusahaan dalam mengelola piutangnya. Perputaran piutang rendah menunjukkan efisiensi penagihan makin buruk selama periode itu karena lamanya penagihan dilakukan". Warrant (2012) mengemukakan bahwa: perputaran piutang mengukur seberapa sering piutang berubah menjadi kas dalam satu tahun”. Berikutnya Stice dan Skousen (2010) yang dimaksud "perputaran piutang adalah cara yang mengukur seberapa sering piutang usaha berubah menjadi kas dalam setahun, dengan cara menghitung pembagian antara penjualan bersih dengan piutang dagang rata-rata yang belum dibayar selama tahun tersebut."

Perputaran Piutang (Receivable Turnover) penting bagi perusahaan dikarenakan semakin tinggi perputaran piutang, maka semakin banyak piutang yang dapat ditagih oleh perusahaan. Sehingga akan memperlancar arus kas dan memperkecil adanya piutang yang tidak tertagih. Alasan lainnya yaitu dengan adanya Perputaran Piutang (Receivable Turnover), maka dapat diketahui bagaimana kinerja bagian marketing dalam mencari pelanggan yang mungkin membeli akan tetapi juga mungkin membayar piutangnya.

Ada dua ukuran yang dapat menghitung tingkat efisiensi piutang yaitu tingkat perputaran piutang atau rata-rata piutang terkumpulnya piutang. Semakin tinggi tingkat perputara piutang tersebut atau semakin cepat piutang dibayar efisien. Tingkat perputaran piutang tergantung dari syarat pembayaran yang diberikan oleh perusahaan. (Prastowo, 2008)

Rumus menghitung rata-rata Piutang:

Rata - rata Piutang $=\frac{\text { piutang awal }+ \text { piutang akhir }}{2}$

Perputaran piutang dapat dirumuskan sebagai berikut: 
Perputaran Piutang $=\frac{\text { penjualan kredit }}{\text { rata rata piutang }}$

Rumus menghitung rata-rata pengumpulan piutang:

Rata - rata pengumpulan piutang $=\frac{360}{\text { perputaran piutang }}$

Representasi dari keberhasilan pengelolaan piutang dapat menggunakan tingkat perputaran piutang karena semakin tinggi tingkat perputaran piutang suatu perusahaan berarti semakin baik pengelolaan piutangnya.

\subsection{Penyesuaian Tarif Air}

Istichori (2018:11) mengungkapkan bahwa "tarif air minum merupakan biaya jasa pelayanan Air Minum yang wajib dibayar oleh pelanggan untuk setiap pemakaian Air Minum yang diberikan oleh BUMN, BUMD, dan UPT. Tarif air minum adalah kebijakan biaya jasa layanan Air Minum yang ditetapkan Kepala Daerah untuk pemakaian setiap meter kubik $\left(\mathrm{m}^{3}\right)$ atau satuan volume lainnya yang diberikan oleh BUMD Air Minum yang wajib dibayar oleh pelanggan."

Widodo (2016:55) menyatakan "Tarif harus terjangkau oleh pelanggan rumah tangga untuk memenuhi standar kebutuhan pokok air minum sehari-hari. Untuk membantu pelanggan yang tidak mampu membayar tarif air minum guna memenuhi standar kebutuhan pokok mereka, PDAM menetapkan tarif rendah atau tarif bersubsidi pada kelompok pelanggan tertentu dan/atau kelompok sosial (termasuk hydran umum). Untuk menciptakan keadilan dan menutup beban subsidi kepada pelanggan yang tidak mampu, PDAM menetapkan tarif yang lebih tinggi bagi kelompok pelanggan yang lebih mampu dan bagi pelanggan yang menggunakan air di atas standar kebutuhan pokok dengan perhitungan dan penerapan subsidi silang."

Harga jual air di PDAM menggunakan istilah "tarif". Penetapan tarif air oleh PDAM diatur dalam Peraturan Menteri Dalam Negeri No. 23 tahun 2006 tentang Pedoman Teknis dan Tata Cara Pengaturan Tarif Air Minum pada Perusahaan Daerah Air Minum (PDAM). Perlakuan tarif PDAM Kota Salatiga mengacu pada Permendagri Nomor 03 Tahun 1998, hal ini tarif ditetapkan dengan Peraturan Walikota atas usulan Direksi Perusahaan Daerah Air Minum yang kemudian disempurnakan dengan Permendagri Nomor 23 Tahun 2006 yang ditetapkan berdasarkan Peraturan Walikota Salatiga Nomor 51 Tahun 2007. Menurut Permendagri No 23 Tahun 2006, pendapatan PDAM harus mencakup prinsip pemulihan biaya, tarif rata-rata minimal harus sesuai dengan biaya dasar sehingga secara penuh diperoleh dari hasil perhitungan. Dalam menentukan seberapa besar tarif air, PDAM juga harus memperhatikan keadaan pelanggan terutama pelanggan rumah tangga. Rumah tangga mencapai kurang lebih $90 \%$ dimana merupakan pelanggan paling banyak di PDAM. Keadaan ini sesuai dengan misi PDAM yaitu mampu mensejahterakan masyarakat, maka tarif yang ditetapkan perusahaan haruslah terjangkau. Tarif yang ditetapkan dalam pemenuhan kebutuhan air untuk pelanggan rumah tangga per bulan tidak lebih dari $4 \%$ dari rata-rata pendapatan rumah tangga yaitu $\mathrm{Rp} 1.735 .000$ per bulan.

\section{METODE PENELITIAN}

Penelitian ini menggunakan metode kualitatif. Metode kualitatif yaitu penelitian yang bermaksud untuk memahami fenomena tentang apa yang dialami oleh subjek penelitian secara holistik, dan dengan cara deskripsi dalam bentuk kata-kata dan bahasa, pada suatu konteks khusus yang alamiah dan dengan memanfaatkan berbagai metode ilmiah. (Moleong, 2007:6)

Objek dari penelitian ini adalah PDAM Kota Salatiga yang berlokasi Jalan Letnan Jend. Sukowati 66/70 Salatiga 50724. Penelitian dilaksanakan pada tanggal 13 Januari 2020 sampai dengan 13 Februari 2020. Subjek utama dalam penelitian ini adalah kenaikan tarif air minum yang mempengaruhi perputaran piutang yang terdapat pada PDAM Kota Salatiga. 


\section{PEMBAHASAN}

Piutang air yang diakui oleh PDAM mencatat jumlah tagihan rekening air pelanggan. PDAM mengakui piutang air pada setiap akhir bulan berjalan proses pendebitan air melalui pipa terpasang oleh pelanggan. Jumlah total air yang didebit oleh pelangan dan tarif golongan pelanggan merupakan dasar dari pencatatan piutang. Total debit air dan tarif pelanggan tersebut menunjukkan total harga air pelanggan. Total penjualan air kepada seluruh golongan pelanggan ditunjukkan dengan harga air pelanggan. Perhitungan harga air dapat diketahui dengan rekapan meteran air pelanggan oleh PDAM setiap tanggal 25-30 tiap bulan berjalan. Jumlah debit air sesuai angka meter pelanggan kemudian akan dikalikan dengan tarif pelanggan sehingga menghasilkan harga air yang harus dibayar pelanggan.

Berdasarkan data yang diperoleh setelah terjadi kenaikan tarif pada tahun 2018, dapat diketahui kenaikan tarif air bersih untuk golongan rumah tangga A sebesar Rp170 per meterkubikdari tarif lama Rp 830 per meterkubik sehinga untuk tarif kategori A menjadi Rp 1.000 per meterkubik. Rumah tangga B sebesar Rp 710 per meterkubik dari Rp 1.490 menjadi Rp 2.200 dan rumah tangga C naik sebesar Rp 915 per meterkubik dari Rp 2.185 menjadi Rp 3.100. Sebelumnya, PDAM Kota Salatiga selama tiga tahun berjalan belum menaikkan tarifnya per tahun 2014. Namun, karena tarif air bersih PDAM Salatiga terhitung masih rendah dibandingkan dengan tarif yang ditetapkan PDAM di Jawa Tengah lainnya, PDAM Kota Salatiga menaikkan tarif air minum. Tarif dasar air bersih mendesak dinaikkan untuk menutup kenaikkan biaya produksi dan operasional akibat inflasi. Selain itu, faktor lain yang menyebabkan kenaikan tarif adalah kenaikan tarif listrik, inflasi, harga BBM, kenaikan harga barang dan biaya operasional PDAM. Selain itu PDAM Salatiga sejak tahun 2014 lalu belum pernah menaikkan tarif air dan kini sesuai peraturan Permendagri Nomor 70 dan 71 Tahun 2016 seharusnya sudah naik pada mulai 1 Januari 2018. Kemudian besaran tarif dasar air sesuai dengan Permendagri tersebut adalah tidak boleh lebih 4 persen dari Upah Minimum Kota (UMK) Salatiga, Rp 1.735 .000 per bulan.

\section{Perputaran Piutang PDAM Kota Salatiga}

Berdasarkan data yang digunakan sebagai penelitian ini adalah laporan keuangan PDAM Kota Salatiga sebelum dan sesudah penyesuaian tarif.

Tabel 1. Perbandingan piutang usaha

\begin{tabular}{|l|l|c|l|c|}
\hline \multirow{2}{*}{ No } & \multicolumn{2}{|c|}{$\begin{array}{c}\text { Penyesuaian Tarif } \\
\text { Per 2014 }\end{array}$} & \multicolumn{2}{c|}{$\begin{array}{c}\text { Penyesuaian Tarif } \\
\text { Per 2018 }\end{array}$} \\
\cline { 2 - 5 } & \multicolumn{1}{|c|}{ Tanggal } & $\begin{array}{c}\text { Piutang Usaha } \\
(\text { Rp })\end{array}$ & \multicolumn{1}{c|}{ Tanggal } & $\begin{array}{c}\text { Piutang Usaha } \\
(\mathrm{Rp})\end{array}$ \\
\hline 1. & April 2017 & $1.002 .230 .282,00$ & April 2018 & $1.284 .883 .375,00$ \\
\hline 2. & Mei 2017 & $1.125 .606 .156,00$ & Mei 2018 & $1.493 .199 .542,00$ \\
\hline 3. & Juni 2017 & $1.023 .620 .584,00$ & Juni 2018 & $1.310 .193 .700,00$ \\
\hline 4. & Juli 2017 & $1.252 .583 .891,00$ & Juli 2018 & $1.573 .636 .355,00$ \\
\hline 5. & Agustus 2017 & $1.163 .803 .026,00$ & Agustus 2018 & $1.415 .150 .945,00$ \\
\hline 6. & September 2017 & $1.144 .263 .513,00$ & September 2018 & $1.432 .859 .805,00$ \\
\hline 7. & Oktober 2017 & $1.248 .161 .975,00$ & Oktober 2018 & $1.543 .076 .500,00$ \\
\hline 8. & Nopember 2017 & $1.151 .708 .586,00$ & Nopember 2018 & $1.456 .659 .255,00$ \\
\hline 9. & Desember 2017 & $1.251 .487 .217,00$ & Desember 2018 & $1.540 .820 .080,00$ \\
\hline 10. & Januari 2018 & $1.241 .458 .959,00$ & Januari 2019 & $1.478 .650 .543,00$ \\
\hline 1. & Februari 2018 & $1.056 .960 .284,00$ & Februari 2019 & $1.300 .221 .075,00$ \\
\hline 12. & Maret 2018 & $1.100 .944 .848,00$ & Maret 2019 & $1.700 .386 .560,00$ \\
\hline & JUMLAH & $13.762 .829 .321,00$ & JUMLAH & $17.529 .737 .735,00$ \\
\hline
\end{tabular}

Rumus tingkat perputaran piutang (receivable turnover) dapat dihitung dengan cara pembagian antara jumlah penjualan kredit selama periode tertentu dengan jumlah rata-rata piutang pada periode tersebut. Berdasarkan data piutang dagang diatas, dapat dihitung besarnya 
perputaran piutang dengan mengasumikan penjualan kredit sebesar Rp 10.000.000.000,00 adalah sebagai berikut:

\section{Data sebelum kenaikan tarif (per 2014)}

$$
\begin{aligned}
\text { Rata }- \text { rata Piutang } & =\frac{\text { piutang awal }+ \text { piutang akhir }}{2} \\
& =\frac{\operatorname{Rp} 1.002 .230 .282+\mathrm{Rp} 1.100 .944 .848}{2} \\
& =R p 1.051 .587 .565 \\
\text { Perputaran Piutang } & =\frac{\text { penjualan kredit }}{\text { rata rata piutang }} \\
& =\frac{\text { Rp 10.000.000.000 }}{\text { Rp 1.051.587.565 }} \\
& =9,51 \mathrm{kali}
\end{aligned}
$$

$$
\begin{aligned}
\text { Rata }- \text { rata pengumpulan piutang } & =\frac{360}{9,51} \\
& =37 \text { hari }
\end{aligned}
$$

\section{Data setelah kenaikan tarif (per 2018)}

$$
\begin{aligned}
\text { Rata }- \text { rata Piutang } & =\frac{\text { piutang awal }+ \text { piutang akhir }}{2} \\
& =\frac{\operatorname{Rp} 1.284 .883 .375+\mathrm{Rp} 1.700 .386 .560}{2} \\
& =\operatorname{Rp} 1.492 .634 .867,5
\end{aligned}
$$

$$
\begin{aligned}
\text { Perputaran Piutang } & =\frac{\text { penjualan kredit }}{\text { rata rata piutang }} \\
& =\frac{\operatorname{Rp} 10.000 .000 .000}{\operatorname{Rp} 1.492 .634 .867,5} \\
& =6,70 \mathrm{kali}
\end{aligned}
$$

$$
\begin{aligned}
\text { Rata }- \text { rata pengumpulan piutang } & =\frac{360}{6,70} \\
& =53 \mathrm{hari}
\end{aligned}
$$

Dari perhitungan di atas dapat diketahui bahwa penyesuaian tarif tahun 2014 dimana sebelum mengalami kenaikan tarif air lebih banyak mengalami perputaran piutang usaha yaitu 9,51 kali dalam satu tahunnya dibandingkan dengan penyesuaian tarif tahun 2018 yang sudah mengalami kenaikan tarif air yaitu sebanyak 6,70 kali. Sehingga perputaran piutangnya turun dan piutang terkumpul dalam waktu kurang lebih 53 hari setelah mengalami kenaikan tarif dari kurang lebih 41 hari pada periode sebelumnya. Kebijakan perusahaan mengenai perputaran piutang adalah 12 kali atau 30 hari rata-rata pengumpulan piutang. Artinya jika selama 1 tahun atau sama dengan 12 bulan dan mengalami perputaran piutang sebanyak 12 kali maka dapat dikata baik, sedangkan apabila dalam 1 tahun terjadi perputaran piutang kurang dari 12 kali maka dapat dikatakan lambat.

Erlita (2017:368) menyatakan: "dengan melihat periode hari rata-rata pengumpulan piutang kita bisa melihat dalam jangka waktu berapa hari piutang akan berubah menjadi kas. Berdasarkan data perhitungan hari rata-rata pengumpulan piutang di atas, hasilnya tergantung pada hasil 
perhitungan perputaran piutang, semakin besar perputaran piutang semakin baik bagi perusahaan, karena modal yang terikat dalam piutang dapat kembali dengan cepat menjadi kas. Periode ratarata pengumpulan piutang lebih besar dari pada batas waktu pembayaran yang telah ditetapkan perusahaan, berarti bahwa cara pengumpulan piutang kurang efisien dan berarti banyak para pelanggan yang tidak memenuhi syarat pembayaran yang telah ditetapkan oleh perusahaan yaitu harapan perusahaan terhadap pengembalian piutang menjadi kas adalah 30 hari sesuai denga ketentuan pelunasan piutang paling lambat 30 hari setelah invoice diterima oleh pelanggan." Berdasarkan penelitian yang diteliti, dapat disimpulkan bahwa hasil perhitungan perputaran piutang per tahun 2014 lebih baik dibandingkan dengan per tahun 2018 meskipun perputaran tersebut masih dikatakan lambat karena dalam 1 tahun mengalami perputaran kurang dari 12 kali. Rata rata pengumpulan piutang per tahun 2014 dan per tahun 2018 dikatakan kurang efisien karena waktu pengembalian piutang menjadi kas melebihi jauh ketentuan pelunasan piutang. Namun, per tahun 2014 rata-rata pengumpulan piutangnya hampir mencapai tingkat efisiensi perputaran piutang.

\section{KESIMPULAN}

Berdasarkan hasil penelitian dan pembahasan yang telah dilakukan mengenai Analisis Perputaran Piutang Sebelum Dan Sesudah Perubahan Tarif Pada PDAM Kota Salatiga, maka dapat ditarik kesimpulan bahwa kenaikan tarif air dapat memperlambat perputaran piutang yang terjadi pada PDAM Kota Salatiga. Perputaran piutang sebelum mengalami kenaikan tarif sebanyak 9,51 kali, sedangkan setelah mengalami kenaikan tarif turun menjadi 6,70 kali setiap satu tahunnya. Sehingga lebih efektif perputaran piutang per tahun 2014 dimana belum mengalami kenaikan tarif.

Berdasarkan hasil analisis dan kesimpulan diatas peneliti menemukan kekurangan yaitu perkembangan perputaran piutang pada PDAM Kota Salatiga menurun dan hasil perputaran piutang per tahun 2014 adalah 9,51 kali dengan rata-rata pengumpulan piutang 37 hari yang artinya perputaran piutang ini dinilai lebih baik dibandingkan sesudah terjadi kenaikan tarif air per tahun 2018. Bagi penelitian yang selanjutnya, sebaiknya mencari data penelitan yang lebih banyak agar mendapatkan hasil yang lebih akurat.

\section{DAFTAR PUSTAKA}

Albertus Yp, B. P. (2015). Pedoman SAK-ETAP PDAM. Jakarta: Persatuan Perusahaan Air Minum Seluruh Indonesia (PERPAMSI).

Anandasari, Y. (2012). Analisis Dampak Penentuan Tarif Air Perusahaan Daerah Air Minum (PDAM) Terhadap Kinerja Keuangan Perusahaan Daerah Air Minum (PDAM). Jurnal Ekonomi Dan Bisnis.

Erlita ML, I. E. (2017). Analisis Piutang Usaha Pada Perusahaan Daerah Air Minum (PDAM) Di Airmadidi Kabupaten Minahasa Utara. Jurnal Riset Akuntansi Going Concern, 357-370.

Euis H, S. I. (2019). Pengaruh Perputaran Piutang Terhadap Tingkat Likuiditas Pada Perusahaan Daerah Air Minum (PDAM) Tirta Raharja Kabupaten Bandung. Fairvalue: Jurnal Ilmiah Akuntansi Dan Keuangan, 13-22.

Istichori, I. P. (2018). Analisis Penentuan Tarif Air Minum Pdam Kabupaten Lamongan Berdasarkan Prinsip Full Cost Recovery. Journal Of Civil Engineering, 10-19.

Iwayan Dyp, I. N. (2013). Analisis Perubahan Penggunaan Air Minum Sebelum Dan Setelah Kenaikan Tarif PDAM Kota Denpasar. Jurnal Ilmiah Elektronik Infrastruktur Teknik Sipil, 1-6.

Juheri. (2009). Analisa Penentuan Tarif Air Minum PDAM Kota Palangka Raya. 1-9. 
Mawiti Iy, I. A. (2020). Analisis Perubahan Penggunaan Air Bersih Sebelum Dan Sesudah Terjadi Kenaikan Tarif PDAM Di Kabupaten Bangli. Jurnal Teknik Pengairan, 22-30.

Niputu La, I. P. (2013). Analisis Tingkat Perputaran Piutang Dagang Pada Pt. Tirta Mumbul Jaya Abadi Periode 2010 - 2012. Vokasi Jurnal Riset Akuntansi, 236-248.

Pemerintah, I. (2006). Peraturan Menteri Dalam Negeri Nomor 23 Tahun 2006 Tentang Pedoman Teknis Dan Tata Cara Pengaturan Tarif Air Minum Pada Perusahaan Daerah Air Minum. Jakarta: Menteri Dalam Megeri.

Putri Eh, R. R. (2018). Pengaruh Perputaran Piutang Terhadap Profitabilitas Pada Toko Mulia Gordyn. Stim Sukma.

Saefi K, A. S. (2015). Pengaruh Perputaran Piutang Terhadap Kinerja Perusahaan Studi Pada Pt. Jaindo Metal Industries. Jurnal Manajemen Dan Bisnis (Performa), 96-121.

Widodo, W. (2015). Analisis Kebijakan Tarif Air PDAM Tirta Asasta Kota Depok, Jawa Barat. Skripsi.

\section{Biodata Penulis}

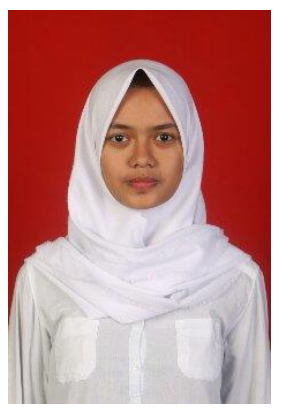

Sofi Agustina, lahir di Kendal, 16 Agustus 1999. Penulis merupakan mahasiswa aktif semester 7 Program Studi S1 Akuntansi, Fakultas Ekonomi di Universitas Tidar yang beralamatkan di Jl. Kapten Suparman No.39, Tuguran, Potrobangsan, Kec. Magelang Utara, Kota Magelang, Jawa Tengah 56116, Indonesia.

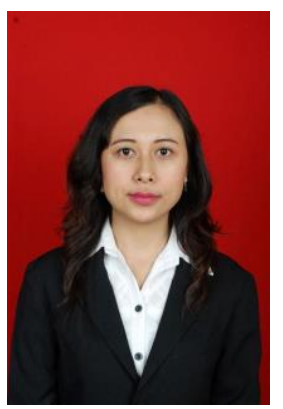

Agustina Prativi Nugraheni, S.Pd., M.Si., lahir pada tanggal 14 Agustus 1991. Penulis merupakan Dosen Akuntansi di Universitas Tidar. Penulis telah menyelesaikan Program Srata (S1) dengan gelar S.Pd di Universitas Negeri Yogyakarta pada tahun 2013 dan Program Magister Akuntansi (S2) dengan gelar M.Si di Universitas Diponegoro pada tahun 2015. 